\title{
What Could the Translation of a 'Retelling' Imply for Translation Studies?
}

\author{
Hilal ÖZTÜRK BAYDERE*
}

The purpose of this study is to scrutinize the implications that The Canterbury Tales: A Retelling (2009) by Peter Ackroyd and its Turkish translation hold for Translation Studies. The study will focus on the translation concepts of 'retelling,' 'intralingual translation,' 'indirect translation,' and 'retranslation.' The motivation for this study stems from the manner in which the books were introduced into the English and Turkish literary systems. The Turkish translation entitled Geoffrey Chaucer'in Canterbury Hikâyeleri (Geoffrey Chaucer's Canterbury tales) (2017) designates Peter Ackroyd as the 'author,' and is presented as a "translat[ion] from the English original" (Ackroyd 2017, 5). In the English edition, on the other hand, Ackroyd appears as the 'translator' of this "original," with Chaucer named as the 'author.' Another noteworthy point is that Geoffrey Chaucer'in Canterbury Hikâyeleri was preceded by other translations of Chaucer's The Canterbury Tales in Turkish. The current study explores how to conceptualize the translational statuses of The Canterbury Tales: A Retelling and Geoffrey Chaucer'in Canterbury Hikâyeleri through discussing the existing definitions of 'retelling,' 'intralingual translation,' 'indirect translation,' and 'retranslation.' This study argues that the English work is, in fact, an 'intralingual (re)translation,' and the Turkish work can be called both an 'indirect translation' and a 'retranslation through indirect translation,' where 'indirect' refers to the process. Along with this, it also offers two new categories for the typology of "intervening texts" in retranslation (Alvstad and Rosa 2015): 'single intralingual retranslation' and 'compilative inter- and intralingual retranslation through indirect retranslation.' The study ends with a discussion of the implications of the English and Turkish works in question with regard to the ideas of 'originality' and 'authorship.'

Keywords: retelling; intralingual translation; indirect translation; retranslation; originality; authorship; The Canterbury Tales

\section{Introduction}

By its very dynamic nature, the field of Translation Studies often encounters conceptual inquiries that arise from within actual translation products and processes. Born out of one of these real-life translation experiences, this paper asks what a 'retelling' and its interlingual translation can bring to the much-debated translation concepts of intralingual

\footnotetext{
* Instructor at Karadeniz Technical University, Trabzon; PhDc at Istanbul University. E-mail: hilalozturk@ktu.edu.tr; ORCID ID: https://orcid.org/0000-0003-1167-8733. (Received 4 July 2019; accepted 16 December 2019)
} 
translation,' 'indirect translation,' and 'retranslation' as well as the less-known concept of 'retelling.' Peter Ackroyd's English edition of The Canterbury Tales: A Retelling (2009) and its Turkish translation entitled Geoffrey Chaucer'in Canterbury Hikâyeleri (Geoffrey Chaucer's Canterbury tales) (2017) provide fertile ground to examine these concepts as they seem to be intermingled throughout these works.

The Canterbury Tales: A Retelling was published by Penguin Books in 2009. Called a 'retelling,' it is a modern prose version of Geoffrey Chaucer's The Canterbury Tales, which was originally in verse form. In this book, Ackroyd is presented as the 'translator' while Chaucer is called the 'author' on the front and inner covers (see fig. 1 and fig. 2 in the appendices). The copyright page indicates that Ackroyd holds the "translation, retelling and introduction" copyright (Ackroyd 2009, copyright page).

In his "A Note on the Text," Ackroyd (2009) expresses that one of the primary motives behind his retelling was providing the possibility for the tales to "be revisited and redefined amid changing circumstances and cultural styles," and therefore to be "reborn in every generation." His retelling of Chaucer, however, has been harshly criticized. To note a few critics, Byron Rogers (2009) approaches the book with suspicion since it is presented as "translation and adaptation" at the same time. Rogers asks why an "accomplished writer" like Ackroyd needs to "adapt" the tales when he admits that "Chaucer's salacious energy can be maintained just by transcribing his words accurately." He questions Ackroyd's choices as a "translator" and argues that "Chaucer would not have welcomed such an adaptation." Rogers also believes that the target audience of the book will not like it because the effect of the tales lies in its original verse form, which is lost in Ackroyd's translation into prose (cf. Rogers 2009).

Germaine Greer (2009), another harsh critic and a writer herself, argues that despite the fluency of the narrative told by Ackroyd, "[t]he charm of Chaucer, the surprises, the myriad gradations of tone, the slyness, the sudden bursts of sweetness, all are sacrificed." Greer criticizes Ackroyd for his characterizations, word choices, the incompatibility of his additions compared to the 14th century conditions, his claims regarding the words he substituted with others because they are not commonly used today, and even his grammar. Describing what Ackroyd did as "clumsy" and "nonsense" in certain parts, she finishes her review advising the readers to "buy Coghill's version plus the acclaimed blank verse version originally published in $1984 \ldots$ and the Bantam dual language printing in the original Middle 
English with translations in parallel." Apparently, Ackroyd's retelling could not avoid the usual criticisms about textual (un)faithfulness: a debate that commonly surrounds modernized versions of classical texts. For instance, Susan Bassnett (2001) had also argued for the modernization of Shakespeare works for contemporary students, but her views were disclaimed by critics on the basis of unfaithfulness (cf. Deveson and Bassnett 2001; Crystal 2002). ${ }^{1}$

As to the Turkish translation of the work, Geoffrey Chaucer'in Canterbury Hikâyeleri was translated by Berna Seden and published by Can Publishing in 2017 (see fig. 3 and fig. 4). The Turkish work includes the note "translated from the English original by Berna Seden"'2 (Ackroyd 2017, 5) and introduces Ackroyd as the 'author,' though giving credit to Chaucer by adding his name to the title. However, what is here presented as an "English original" was introduced to the English literary system as a "retelling" and "translation" (Ackroyd 2009).

Another fact worth mentioning is that Chaucer's The Canterbury Tales had already appeared in the Turkish literary system before Seden's translation. Nazmi Ağıl's widely acclaimed direct translation from The Canterbury Tales was published by Yap1 Kredi Publishing in 1994. In addition to that, Burçin Erol produced a partial translation in 1993, and a simplified version for children was produced by Sibel Alaş (2017). ${ }^{3}$

Geoffrey Chaucer'in Canterbury Hikâyeleri received a critical review in Turkey, similar to Ackroyd's retelling in English circles. Asuman Kafaoğlu Büke (2017), a Turkish writer and critic, compares Ağ1l's translation (1994) and Seden's translation (2017). She praises A $\breve{g l l}$ 's translation by saying that "his translation allows the contemporary Turkish reader to delve into the story without sacrificing humor and pleasantness" and introduces Seden's work as another translation of The Canterbury Tales, highlighting its prose form rather than verse. She acknowledges Ackroyd's comprehensive knowledge of Chaucer and his works but, nevertheless, finds his endeavor "inconsequential" for non-English audiences who read Chaucer through translation. Hence, she recommends reading A $\breve{g}_{1} l$ 's translation rather than "Ackroyd's simplified version" found in Seden's translation.

\footnotetext{
${ }^{1}$ For a study on similar debates within the context of Turkish classics, see Öztürk Baydere 2019.

${ }^{2}$ Translations are mine unless otherwise stated.

${ }^{3}$ For a study comparing Ağıl's and Erol's translations of "General Prologue," see Reis 2001.
} 
Moving past these multifaceted debates surrounding the retelling in question and its Turkish translation while engaging the insights they provide for concepts of translation, this study will offer a brief overview of Chaucer's The Canterbury Tales and Peter Ackroyd first. It will then conduct a conceptual exploration of the works in question with regard to the concepts of 'retelling,' 'intralingual translation,' 'indirect translation,' and 'retranslation.' After seeking to position the texts in question within the translation theory framework, the study will end by noting the implications of this case in regard to the ideas of 'originality' and 'authorship.'

\section{Geoffrey Chaucer and The Canterbury Tales}

Written in the 14th century in Middle English in verse form, The Canterbury Tales is considered one of the earliest and most influential works of the English literature. It became so popular that there were "more than eighty" surviving manuscripts collected following the poet's death: a striking number for the early years of the 15th century (David and Simpson 2006a, 217). Chaucer himself was called "the Father of English poetry" by later writers, and, thanks to The Canterbury Tales, he played an important role in "enhanc[ing] the prestige of English as a vehicle for literature of high ambition" (David and Simpson 2006b, 2). Because it was written in Middle English, The Canterbury Tales has been introduced into contemporary readers through many 'modern,' 'adapted,' 'retold,' etc. forms, besides its interlingual translations. ${ }^{5}$

\section{Peter Ackroyd and His Works}

Peter Ackroyd is a British author and a translator of The Canterbury Tales. As a prolific writer, he is particularly praised for his fictional works blurring the distinction between past and present as well as reality and fiction (Onega 1996, 208). According to his biography on the website of "The British Council," ${ }^{6}$ his works generally deal with "the city of London, its history, literature, culture, and people," leading him to be known as a "London writer." In addition to his biographies of acclaimed figures such as Ezra Pound, T. S. Eliot,

\footnotetext{
${ }^{4}$ For a discussion of the term 'retelling' compared with 'rewriting,' see Öztürk Baydere 2018.

${ }^{5}$ For a study discussing interlingual translations of Chaucer's The Canterbury Tales as well as "neo-Chaucerian" works, see Barrington and Hsy 2015.

6"Peter Ackroyd," British Council Literature, accessed July 1, 2019, https://literature.britishcouncil.org/writer/peter-ackroyd.
} 
and William Blake, he also writes fictional works, e.g. The Last Testament of Oscar Wilde (1983) and Hawksmoor (1985), about literary figures and "real-life historical characters." Some of his works are inspired by well-known canonical works such as The Clerkenwell Tales (2003), which is "set in medieval London, [and] draws on Chaucer's The Canterbury Tales and features many well-known characters." Following this fictional work, "Ackroyd then went on to produce a more direct re-write of Chaucer's classic poem, The Canterbury Tales: A Retelling (2009)." It should be noted that in between writing the fictional work entitled The Clerkenwell Tales and retelling The Canterbury Tales, Ackroyd also wrote a biography of Chaucer himself (see Ackroyd 2004).

\section{Conceptualizing The Canterbury Tales: A Retelling and Geoffrey Chaucer'in}

\section{Canterbury Hikâyeleri}

From the perspective of Translation Studies, presenting The Canterbury Tales: A Retelling as both a 'retelling' and a 'translation' of Chaucer's work seems worthy of consideration, given the relatively limited coverage of the term 'retelling' in the literature and the extremely harsh criticism on Ackroyd's work. Because the translation involved a transition from Middle English to modern English as well as from poetry to prose, it seems worth examining the work from the standpoint of an 'intralingual translation.' Taking Ackroyd's retelling as a translation, one could argue that Geoffrey Chaucer'in Canterbury Hikâyeleri should be viewed as an 'indirect translation,' because it is a "translation of a translation" (Gambier 2003, 57) and seems to challenge certain assumptions associated with the concept 'indirect translation' contained in Translation Studies literature. Lastly, the fact that the Turkish translation of Ackroyd's retelling was preceded in Turkish by other translations of Chaucer's The Canterbury Tales makes an interesting case for revisiting categorizations on texts that are involved in retranslations and the directness/indirectness of retranslations.

\footnotetext{
${ }^{7}$ This is not Ackroyd's only 'retelling.' He also produced a 'retelling' of Thomas Malory's Le Morte d'Arthur (The death of Arthur) (1485) in 2010.
} 


\subsection{Retelling}

The online Oxford Dictionary defines 'retelling' as "tell[ing] a story again, often in a different way." 'Retelling' is a commonly used method for promoting literary works that are produced for a new audience by someone other than the author (Leatherbarrow 2002; Eubanks 2012).

A look at the main Translation Studies references reveals that in the four volumes of the Handbook of Translation Studies published from 2010 to 2014, the Dictionary of Translation Studies ([1997] 2014), and the Routledge Encyclopedia of Translation Studies (2011), no separate entry for 'retelling' exists. In conjunction with that, Susanne Mørup Hansen (2005) highlights that there is no "acknowledged definition of a retelling, let alone a translation" (172). The Routledge Encyclopedia of Translation Studies (2011), however, involves the term 'retelling' in Keneva Kunz's entry entitled "Icelandic Tradition." It is used to describe some traditional Icelandic works based on foreign works in order to distinguish them from works that were "“translated' directly" (cf. Kunz 2011, 443), and to refer to books composed of "older historical poems" and "intended for the amusement of the common people" (cf. 446). The term 'retelling' is also encountered in Ramesh Krishnamurthy's (2011) entry entitled "Indian Tradition" where it is part of a stated attempt at "distinguishing between retellings ... and actual translations" (cf. 450). In this case, it can be said that 'retelling' is not identified with 'translation.' Rather, the term is used to refer to some translational processes that are different from 'translating directly' or doing 'actual translation.' This is reminiscent of the identification of 'translation proper' with 'interlingual translation' (Jakobson [1959] 2004, 233).

As to the work under consideration, Ackroyd explains his overall view on translation and the path he took in his work as follows:

There are no laws of translation. There are no general rules. . . Who can determine in advance how a certain word or phrase should be most finely rendered? In the case of The Canterbury Tales, for example, it would have been possible to follow the example of John Dryden, whose inventive and exuberant translation of 'The Knight's Tale' . . was free translation of the very best. Or it would have been possible to follow the stricter and more faithful model of Nevill Coghill's translation of the entire Canterbury Tales ... I chose to follow neither example. Translation can be a form of

\footnotetext{
8"Retell," Oxford Learner's Dictionaries, accessed July $\quad 1, \quad 2019$, https://www.oxfordlearnersdictionaries.com/definition/english/retell.
} 
liberation, releasing an older work into the contemporary world and thereby infusing it with new life. . . . So I thought it best to approach my own task in the manner of Chaucer himself, whose translation of part of the Roman de la Rose (to give one of many examples) was faithful to the spirit if not always to the letter of the great original. He seems to have worked on the principle of inspired improvisation, guided by no other criterion than his own good sense. (2009, under "A Note on the Text")

Obviously, Ackroyd views retelling not as less than 'translation,' but rather part of it, as he puts it within a wide range of paths that could be followed through translating, which, he asserts, has "no laws." Thus, his stance appears to be opposed to labeling his retelling as 'not an actual translation.'

Ackroyd's emphasis on "liberat[ing]" and "infusing [a work] with new life" clearly evokes what Judy Wakabayashi (2012) mentions in "Secular Translation: Asian Perspectives." In speaking about issues of authorship and creativity, Wakabayashi states, "with retellings, creativity lay [sic] in breathing new life into existing works." This may actually account for why the term 'retelling' is often used for versions intended for a particular new audience. Wakabayashi also adds that within the Japanese context, "adaptations and retellings of children's literature ... have blurred distinctions between author and translator and between original works and reworkings" (under "Authorship and Creativity"). That the Turkish translation of Ackroyd's retelling presents Ackroyd as the 'author' and states that it is a "translat[ion] from the English original" (Ackroyd 2017, 5) may be related to this characteristic of 'retellings' that challenges the traditional binary oppositions.

Ackroyd's stated purpose in his retelling is "facilitat[ing] the experience of the poemremov[ing] the obstacles to the understanding and enjoyment of the tales, and by various means intimat[ing] or express[ing] the true nature of the original." He features the possibility of "intimat[ing] the nature of the poetry within the texture of the prose" and "indirectly and almost subliminally echo[ing] the euphonies and harmonies of Chaucerian verse." $\mathrm{He}$ changed words potentially "unfamiliar" to contemporary readers in order to prevent the "lay reader" from being "delay[ed] or confuse[d]," and he omitted two tales because of their medieval aspects that are "now irrevocable," as well as rearranging the order of the tales to "convey the sense of a fitting ending" (Ackroyd 2009, under "A Note on the Text"). While 
previous studies dealing with 'retelling' from the perspective of Translation Studies are few, ${ }^{9}$ one idea that emerges from them is that a work is called a 'retelling' when it involves a relatively high degree of deviation from the source text. A notable example of the use of the term to indicate such textual deviation is for Lin Shu's Chinese translation of La Dame aux Camélias (The lady with the camellias) in the late-Qing period. Laurence Wong (1998) calls the work "story-retelling" because the translator engaged in "making changes and adaptations" (209), "condensing," "rewriting" (216), "abridg[ing]" and so on, since he could not understand the source text thoroughly. The translator's unfamiliarity with the source language, Wong states, prevented him from "translat[ing] directly from the source language" and caused him to make "many flaws" in the translation process (230).

Back to Ackroyd's retelling, his modifications have, not surprisingly, been subjected to various faithfulness-oriented criticisms. Critics disparage the retelling as incurring Chaucer's disapproval as well as the dislike of the target audience, losing the unique effect of the work due to the shift in genre (Rogers 2009), and forfeiting its Chaucerian charm via the modernization process (cf. Greer 2009). These criticisms, however, spark another question: faithfulness to whom? ${ }^{10}$ Given that Ackroyd (2009) himself acknowledges in the very beginning of his work that his purpose is to give today's readers an experience that is free from "delay" or "confus[ion]," one can reasonably argue that his faithfulness was oriented towards both his audience and "the spirit, if not always to the letter [of the source]" (under "A Note on the Text"). This approach resonates with Gordon McGregor Kendal's (2008) call for broadening the concept of translation by incorporating many other related terms, including "retelling." He argues that engaging the readers in a story is also a type of faithfulness (cf. iiiii). Given these considerations, taking Ackroyd's retelling as a translation from Middle English to modern English allows for a discussion of the work within the framework of 'intralingual translation.'

\footnotetext{
${ }^{9}$ For a study dealing with the term 'retelling' in terms of court interpreting, see Ralarala 2014. For some other studies using the term 'retelling' from a variety of perspectives within the field of Translation Studies, see Beckett 2003; Oittinen 2008; Mehtonen and Hakkarainen 2013; Pagello 2013; Canl1 2019a. For studies taking 'translation' as a form of 'retelling', see Pimentel 1998 and Bassnett 2011.

${ }^{10}$ For a study discussing translation theories and translation criticism based on source-orientedness vs. targetorientedness, see Bengi-Öner (1993) 1999. For a study discussing the traditional faithfulness-oriented discourse with a reference to the translator's identity and translator training, see Öner 2013, and for a Lacanian analysis of discourse on faithfulness, see Öner 2018.
} 


\subsection{Intralingual Translation}

In Jakobson's ([1959] 2004) famous tripartite categorization of translation, intralingual translation (rewording) is defined as "an interpretation of verbal signs by means of other signs of the same language." Jakobson adds, "[t]he intralingual translation of a word uses either another, more or less synonymous, word or resorts to a circumlocution. Yet synonymy, as a rule, is not complete equivalence" (114). In the Dictionary of Translation Studies ([1997] 2014), Mark Shuttleworth and Moira Cowie give examples of intralingual translation as "simplifying a technical text for a non-specialist readership, adapting a classic for a children's audience or producing a version of Chaucer in modern English" (87-88; emphasis mine). ${ }^{11}$ This identification of the modern versions of Chaucer's works as 'intralingual translation' in this basic reference of Translation Studies further corroborates labeling Ackroyd's retelling as an 'intralingual translation': a position which is further strengthened by its introduction as a 'translation.' Taken as a whole, the work stands as a modern 'interpretation' or 'rewording' of Chaucer's tales written in the 14th century and also fulfills the three postulates put forward by Gideon Toury (1995) for classifying a work as "(assumed) translation": the source-text postulate, the transfer postulate, and the relationship postulate (33-35). As an intralingual translation, the work is also an "intergenre translation"12 (Perteghella 2013, 205), since it is a translation from verse to prose.

Including multiple sub-categories such as "expert-to-layman" and "oral-to-written," intralingual translation is a subject of rising interest to Translation Studies scholars (cf. Delabastita 2017; Zethsen 2018). ${ }^{13}$ The multiplicity of concepts referring to intralingual translations is noteworthy. For example, despite being rich in intralingual translationsmainly due to the Turkish Language Reform (1928) introducing the Latin alphabet ${ }^{14}$

\footnotetext{
${ }^{11}$ Whether old forms of a language and its contemporary form can be considered the same language may be another point of conflict, with potential to raise questions as to what can be taken as 'interlingual translation' and what is 'intralingual translation.' For a study discussing this aspect of old and contemporary English, see Delabastita 2017 - a case study using Shakespeare modernizations and arguments surrounding those translations. ${ }^{12}$ For a study discussing 'intergenre translation' within the context of 'self-translation' and offering conceptual proposals, see Baydere and Karadağ 2019.

${ }^{13}$ For a recent study discussing the reception of intralingual translations, see Karas 2020. For some others addressing the position of the intralingual translation within Translation Studies, see Zethsen and Hill-Madsen 2016. For a study contrasting intralingual translation and interlingual translation, see Mossop 2016, and for those evaluating 'rewriting' based on the term 'intralingual translation,' see Canl1 2018; Screnock 2018; Canl1 2019 b.

${ }^{14}$ For some studies on intralingual translations as modernizations within the Turkish context, see Berk Albachten 2013, 2014, 2015. For a study focusing on the repositioning of intralingual translation as part of translation history, see Berk Albachten 2019. For a recent study focusing on the manipulative aspect of intralingual
} 
Turkish literary and cultural system tends to refrain from using the term intralingual translation.' Instead, intralingual translations are introduced under other names such as "simplified," "Turkicized," "arranged," or "prepared for publishing," among many others (Berk Albachten 2015, 171). ${ }^{15}$ This observation holds true for Ackroyd's retelling as well. Despite being designated as a 'translation,' it is not called an 'intralingual translation. ${ }^{16}$ On the other hand, it can be argued that addressing the retelling under consideration as an '(intralingual) translation' opens up the way for further exploration into two other basic, yet highly-debated, translation concepts: 'indirect translation' and 'retranslation.'

\subsection{Indirect Translation}

Taking The Canterbury Tales: A Retelling as an '(intralingual) translation,' its Turkish translation entitled Geoffrey Chaucer'ın Canterbury Hikâyeleri appears to be an 'indirect translation' as it is the "translation of a translation" (Gambier 2003, 57). There is not a consensus among scholars on a single definition for that term, however, and each new definition contributes different nuances to the concept. In the Dictionary of Translation Studies ([1997] 2014), the term 'indirect translation' is said 'to denote the procedure whereby a text is not translated directly from an original ST, but via an intermediate translation in another language" (Shuttleworth and Cowie, 76$).{ }^{17}$

Addressing 'indirect translation' within "preliminary norms" governing translational acts, Toury (1995) associates it with "translating from languages other than the ultimate source language" (58). Yves Gambier (2003), on the other hand, provides a broader definition: "translation of literary works, based on a translated version of the original text"

\footnotetext{
translations, using Nutuk (1927) by Mustafa Kemal Atatürk as a case study, see Kalem Bakkal 2019. For an ongoing PhD dissertation on the intralingual translation of Çalıkuşu (1922), a Turkish classic, with a range of conceptual discussions, see Baydere 2019.

${ }^{15}$ For a discussion of these terms, see Berk Albachten 2015 and Canseven 2017.

${ }^{16}$ For the discussion of a similar case in Turkish where two different Latinized versions of the same work involving quite similar translational strategies are named differently (i.e., "transcription" and "translation"), but neither designated as "intralingual translation," see Karadağ 2017.

${ }^{17}$ The term is also used by Ernst August Gutt (1989) to refer to one of the two types of translation he suggests: "direct translation" and "indirect translation." To him, "direct translation corresponds to the idea that translation should convey the same meaning as the original, including stylistic effects, and indirect translation involves looser degrees of faithfulness" (2).
} 
(57). ${ }^{18}$ As a translation of an intralingual translation, this definition can be said to cover Seden's Turkish translation of Ackroyd's retelling.

Previous studies on indirect translation basically focus on the purposes underlying indirect translation, when the need for indirect translation arises, and how indirect translations are perceived by the target audience (Pięta 2014; Rosa, Pięta and Maia 2017; Canl1 2019b). Several negative perceptions of indirect translations are common. Indirect translations are perceived to create extra distance from source texts and are "often hidden or camouflaged" (Rosa, Pięta and Maia 2017, 113). They are considered inferior to direct translations as a "poor copy of . . . [another] poor copy" (Pięta 2014, 16), and they are thought to arise mainly from the unavailability of translators with linguistic competence in the relevant languages and through efforts at cost-effectiveness (22). These assumptions regarding indirect translation seem to be challenged by the work under consideration.

First, indirect translations are claimed to bring 'extra distance' between the source text and the target audience and hence to be "often hidden or camouflaged" (Rosa, Pięta and Maia 2017, 113). However, in line with Ackroyd's stated aim to facilitate the reading experience for contemporary readers, the Turkish translation - indirect translation - is published with the note, "Chaucer's immortal work now meets readers with a contemporary interpretation in a revived form in prose without losing its harmony" (Ackroyd 2017). Thus, it is possible to say that the indirect translation in view attempts to close the gap between the source text and the target audience rather than creating extra distance. In addition to that, there is no attempt to 'hide' or 'camouflage' the indirectness of the translation.

Second, it is assumed that indirect translations are inferior to direct translations as 'poorer copies of poor copies.' Kafaoğlu Büke's (2017) comments on Geoffrey Chaucer'in Canterbury Hikâyeleri fall along these lines, as she prioritizes Ağıl's direct translation (1994) from Chaucer's Middle English version in verse form, despite the fact that she also gives credit to Seden's translation:

Ackroyd certainly provides a great contribution for those who read Chaucer in English. For the rest of us who already read Chaucer through translation, however, his endeavor is less significant. I recommend that you read the translation of the original text rather than Ackroyd's simplified version, though I must add that Berna Seden's translation is successful.

\footnotetext{
${ }^{18}$ For some recent studies on what 'indirect translation' covers, see Pym 2011; Špirk 2011; Ringmar 2012; Washbourne 2013; Marin-Lacarta 2017; Pięta 2014, 2017.
} 
Kafaoğlu Büke (2017) praises Seden's translation yet calls it a translation of a 'simplified version' and suggests not reading it because Turkish already has Ağıl's translation that is a product of "substantive labor," "understandable by contemporary [Turkish] readers," and that "reflects the author's [Chaucer's] whole humor and sweetness." In this way, Kafaoğlu Büke seems to reject the validity of the purpose intended by Ackroyd, Seden, and Can Publishing for the Turkish audience. By affirming Seden's translation of Ackroyd's work as a 'direct translation' while rating the end result as insignificant since it was not based on Chaucer's original text, she, consciously or unconsciously, communicates her disregard for 'indirect translation.' Evaluating the worth of a translated work based on its source appears to have created an inner conflict for her, leading her to find Seden's work "successful" while recommending "not reading it." Kafaoğlu Büke's ambivalence can be understood in terms of Işın Bengi-Öner's remarkable views on source-oriented perspectives on translation. She argues that process-oriented, source-oriented, and prescriptive approaches to translation are inherently contradictory and subjective because they are not grounded in real translational phenomena. She notes that criticisms based on such views assume that there is "a certain level of translation where static quality is attainable" (cf. Bengi-Öner [1993] 1999, 117). Interestingly enough, despite the fact that indirect translation is associated with 'inferiority,' the current case study seems to indicate the opposite, and Ackroyd, who appeared as the 'translator' in the English work (i.e., the direct translation), is taken as the 'author' in the Turkish work, thereby challenging traditional and historical conceptions of author-translator statuses.

Third, the claim that the unavailability of linguistically competent translators in the relevant languages is the main factor in the production of indirect translations is challenged by Seden's indirect translation, since her translation stems, not from a lack of competent translators, but from an intention to bring a new, contemporary interpretation of Chaucer's The Canterbury Tales to the modern Turkish audience. The above-mentioned claim includes an implicit assumption: indirect translations are followed by direct ones. In this case, however, Seden's indirect translation (2017) follows A ğıl's direct translation (1994) and controverts this implicit claim, which reduces 'indirect translation' to the use of an intermediary language and text just to facilitate the access to the target audience.

Given all this, in light of Seden's translation, it seems appropriate to view indirect translation as an independent category of translational work that goes beyond serving as a 
mere facilitating device for accessing a work through an intermediary language. Establishing indirect translations as a freestanding category could pave the way for further discussions about their value and position in relevant literary systems. In the current case, for example, the appearance of Geoffrey Chaucer'in Canterbury Hikâyeleri as an indirect translation after Ağll's translation in 1994 also introduces a discussion about the concept of 'retranslation.'

\subsection{Retranslation}

In the Routledge Encyclopedia of Translation Studies (2011), 'retranslation' is defined as "either the act of translating a work that has previously been translated into the same language, or the result of such an act, i.e., the retranslated text itself" (Tahir Gürçağlar 233). Kaisa Koskinen and Outi Paloposki (2010), on the other hand, define it as "a second or later translation of a single source text into the same target language" (294). Based on these definitions, The Canterbury Tales: A Retelling can appropriately be called an intralingual retranslation. Many contemporary English versions of The Canterbury Tales were published before it: Nevill Coghill's widely acclaimed edition (1951) being the first. Labeling Geoffrey Chaucer'in Canterbury Hikâyeleri as an indirect translation ${ }^{19}$ of Chaucer's The Canterbury Tales introduces the possibility of calling it a 'retranslation' as well, since The Canterbury Tales has already been translated into Turkish as a complete text (A $\breve{g}_{1} 1$ 1994), a partial text (Erol 1993), and in a simplified form (Alaş 2017). It is, after all, a translation, if an indirect one, of The Canterbury Tales which "has previously been translated into the same language [i.e. Turkish]" (Tahir Gürçağlar 2011, 233). From the perspective of Koskinen and Paloposki's (2010) definition, it can be taken as a "later translation of [The Canterbury Tales] into the same target language" (294), even though it was translated into Turkish through another text. This is affirmed by Kafaoğlu Büke's review of Seden's work: "Last week, another The Canterbury Tales was published in prose form by Ackroyd" (2017; emphasis mine).

The indirectness of the translation under consideration seems to shed light on a different aspect of 'retranslation,' i.e., the nature of the texts serving as the 'source' of (re)translations. Some discussions of this topic have already emerged in Turkish literary and cultural circles addressing retranslations produced from differing source texts. Ayşe Banu

\footnotetext{
${ }^{19}$ The term 'retranslation' is also used "in the sense of (the subordinate or a hyponym of) indirect translation" (Rosa, Pięta and Maia 2017, 117) in that indirect translation involves 're-translating' a text already translated.
} 
Karadağ (2008, 107-152) compares three different translations of Robinson Crusoe (1719) into Ottoman script by three different translators. She notes that one of the translators, Şemseddin Sami, produced an indirect translation of the work through Arabic (1886). Another translation, published by Resimli Ay Publishing in 1927, lacks both the translator's name and any information about the language from which the translation took place, but the number of the pages (i.e., 59 pages) indicates that it is either an abridged version or a translation from an abridged version. The translator of the third translation is Mehmed Ali; the date of publication, however, is not mentioned. Karadağ surmises that this translation is likely an indirect translation as well since the page count is low. These three translations, despite their disparate origins and translation methods, are all considered retranslations of Robinson Crusoe in the Ottoman literary system. Another recent study along these lines is Hülya Boy's (2019b) study, examining three translations of The Picture of Dorian Gray (1890, 1891, 2011) in Turkish. They are based, respectively, on the book version, the uncensored version, and the magazine version of the source text in the source literary system. According to Boy, the fact that The Picture of Dorian Gray ${ }^{20}$ was rewritten and reinterpreted in multiple textual mediums in the source literary system necessitates revisiting the concept of retranslation within the target texts being translated from the different source texts associated with an original work (169). From this standpoint, taking Geoffrey Chaucer'ın Canterbury Hikâyeleri as an (indirect) translation of The Canterbury Tales invites theoretical and typological discussions regarding the directness of retranslations and the texts involved in them. As a matter of fact, according to Cecilia Alvstad and Alexandra Assis Rosa (2015),

Addressing retranslation as an object of study ${ }^{21}$ in its own right involves the task of conceptualization. ... The work also requires the sub-specification of retranslation so as to construct an adequate typology and identify relevant criteria for its definition and study. (8)

\footnotetext{
${ }^{20} \mathrm{~A} \mathrm{PhD} \mathrm{dissertation} \mathrm{addressing} \mathrm{the} \mathrm{intralingual} \mathrm{and} \mathrm{interlingual} \mathrm{translations} \mathrm{of} \mathrm{The} \mathrm{Picture} \mathrm{of} \mathrm{Dorian} \mathrm{Gray}$ through an extensive conceptual discussion of some foundational translation concepts is currently being prepared by Boy (2019a) under the supervision of Ayşe Banu Karadağ at Yıldız Technical University (Turkey).

${ }^{21}$ For a study "organiz[ing] the main tenets of . . research on retranslations by applying . . . the Five W's and One H approach (what, who, where, when, why, and how)," see Alvstad and Rosa 2015. For some recent studies on retranslation and ideology, see Birkan Baydan 2015; Kim 2017; Konca 2019; Özmen 2019. For some studies on retranslation employing paratextual elements, see Güneş 2018; Demirkol Ertürk 2019; Eker-Roditakis 2019; Erkul Yağcı 2019; Ziemann 2019. For those on retranslation methodology, see Güneş 2019; Koskinen 2019; Widman 2019, and those on conceptualization in retranslation, see Koskinen and Paloposki 2010; Geçmen 2018; Güneş 2019. For some studies involving surveys or bibliographies of retranslation studies, see Van Poucke 2019; Berk Albachten and Tahir Gürçağlar 2019.
} 
The retranslational aspect of Seden's translation calls for a consideration of its (in)directness. Along these lines, Xu Jianzhong (2003) proposes two "kinds of retranslations":

... there are two kinds of retranslations: direct and indirect. Direct retranslation refers to the translation for the second or more times from the original. Indirect re/translation refers to the translation not from the original but from the other language retranslation(s) translated from the original. (193)

Obviously, his definition of "indirect re/translation" involves three languages: the source language, the intermediary language, and the target language. Therefore, he uses the term 'indirect retranslation' to refer to retranslations produced by using the same translation in an intermediary language as source text. 'Direct retranslation,' on the other hand, refers to retranslations from a single source text without any intermediary text/language (cf. Jianzhong 2003). How does Seden's translation fit within this nomenclature system? It cannot be an 'indirect retranslation' of Chaucer's The Canterbury Tales, because there are not three languages in view, but neither is it a 'direct retranslation,' since it is not being directly retranslated from Chaucer's source text. Thus, Seden's work calls for a new coupling of the terms 'indirect' and 'retranslation.' This study proposes the designation 'retranslation through indirect translation,' where 'indirect' refers to the process. This designation could create subcategorizations for describing retranslations in terms of their source texts: 'retranslation through direct translation' and 'retranslation through indirect translation.' Within such a subcategorization framework, the former designation would refer to retranslations produced by direct translation from a work, and the latter to retranslations of a work that are produced by translating from one or more existing translations of it.

In another typological study of retranslations, Alvstad and Rosa (2015) provide a categorization to "profile voice in retranslation" (17-18) and list the "type[s] of intervening texts for retranslation" as follows:

a. Use of a source text in the source language only (despite pre-existing translations into the target language): single interlingual retranslation;

b. Use of the source text and of one or several previous translations into the target language: compilative inter- and intralingual retranslation;

c. Use of one or several pre-existing translations as the sole source text(s): single/compilative intralingual retranslation without recourse to the source text and language and resorting only to pre-existing target-language translations. (17; emphasis in the original) 
Karadağ (2019) added another category to this categorization of texts involved in retranslations: "single inter- and intralingual [self] retranslation" (46-47). This category refers to the second translation of a work by the same translator based on his/her previous translation into the target language.

The English and Turkish retranslations under scrutiny in the present study, however, do not seem to fit any of these categories. Ackroyd's intralingual retranslation in English, using Chaucer's Middle English text as its source, seems to be the closest to category a (i.e., single interlingual retranslation). Since it is an 'intralingual' work, however, it is not covered by category a and requires a new category. In this regard, the current study proposes 'single intralingual retranslation,' referring to the use of a single source text in intralingual retranslations. The Turkish retranslation entitled Geoffrey Chaucer'in Canterbury Hikâyeleri also does not fit into Alvstad and Rosa's categories. Seden, the Turkish translator, placed a footnote in her translation of "Introduction" prepared by Ackroyd, stating that some of the Turkish verse translations in that section were borrowed from Ağll's Turkish translation (Ackroyd 2017, 18). Her use of Ağ1l's translation was not limited to that, however, as she borrowed the translations of the names of the characters from that previous Turkish translation as well. Therefore, it is obvious that Seden used both Ackroyd's English text (i.e., the intralingual translation of the source text) and Ağıl's Turkish translation to produce her retranslation. Considering the categories above, Seden's retranslation seems to be close to category $b$ (i.e., compilative inter- and intralingual retranslation), since it is based on both an English and a Turkish text. Nevertheless, its 'indirect' character-Seden does not use Chaucer's original work-begs the addition of another category. Thus, in light of the designation proposed above ('retranslation through indirect translation'), this study suggests the specification, 'compilative inter- and intralingual retranslation through indirect retranslation.' With the designations proposed, the study intends to contribute to "construct[ing] an adequate typology and identify[ing] relevant criteria for definition and study [of retranslation]" (Alvstad and Rosa 2015, 8).

With the conceptual examination and categorization of The Canterbury Tales: $A$ Retelling and Geoffrey Chaucer'in Canterbury Hikâyeleri, necessitated by the multifaceted nature of the works, now complete, the study turns to discussing the implications of these works within the context of 'originality' and 'authorship.' The study will particularly consider the faithfulness-focused criticisms directed toward the English work as a 'retelling' with 
transLogos 2019 Vol 2 Issue 2

Öztürk Baydere, Hilal, pp. 102-133

trans Logos

A Translation Studies Journal

What Could the Translation of a 'Retelling'

Imply for Translation Studies?

(C) Diye Global Communications diye.com.tr|diye@diye.com.tr

reference to the 'original' and the difference of 'author' names as designated in the English and Turkish works.

\subsection{Originality and Authorship}

The nature of the works under consideration leads to the questioning and broadening of certain translation concepts as elaborated above. They also seem to suggest an absence of clear-cut distinctions between 'original' and 'translation,' as well as a certain mutability in the status of 'author' and 'translator.' Since it is beyond the purpose and scope of this paper to make an in-depth conceptual analysis of these terms, only the implications of the case under consideration are touched upon here.

According to Itamar Even-Zohar ([1978] 2000), "what is a translated work cannot be answered a priori in terms of an a-historical out-of-context idealized state" (197; italics in the original). It seems necessary, then, to evaluate the 'originality' and 'translational status' of these works within their own contexts, especially considering the harsh criticisms received by Ackroyd's retelling with regards to its 'original.'

Traditionally, 'originals' and 'authors' have been preferred to 'translations' and 'translators,' respectively, and "translation [was] seen as the poor relation of writing, often referred to as 'original' or 'creative' writing, and widely perceived as superior" (Bassnett 2006, 173). This has not always been true, however. "Until the early nineteenth century authorial originality was not accorded a privileged position in Europe, but the advent of Romanticism led to a valorization of authors . . . over translators . . . and a greater differentiation between the two roles" (Wakabayashi 2011, 87).

Chaucer is also reported to have gained "status and authority" through translation in a period (the Middle Ages) when the distinction between 'original' works and 'translations' "did not exist" (Bassnett 2006, 173):

For Geoffrey Chaucer ... who is generally recognized as England's greatest medieval poet, translation was a fundamental activity. Writing in the vernacular at a time when Latin still enjoyed considerable cultural prestige, Chaucer obtained status and authority through his work as a translator and compilator. (Machan 1989 quoted in Woodsworth 2012, 61; emphasis mine, italics in the original)

However, despite his claims that he gave The Canterbury Tales a new life by employing Chaucer's own style of translation, Ackroyd could not avoid faithfulness-oriented 
criticisms. One of the critics even claimed that Chaucer would not approve "such an adaptation" (cf. Rogers 2009). Nevertheless, "for Chaucer, as for other early vernacular writers, there was an overlap between translation, compilation, rewriting and original authorship. The conception of translation as re-creation was a means to resolve these tensions" (Woodsworth 2012, 61).

Perhaps these criticisms arose from the understanding that, as Banu Tellioğlu (2019) states in her treatment of the historical view of 'originality' and 'copyright,' a work must contain a distinguishing feature that makes it unique, and this feature is not the "ideas per se, but rather ... the unique 'form' in which an author chose to express these ideas" (Hesse 2002, 35 quoted in Tellioğlu 2019, 133). At this point, it is important to note that, no matter how deep-rooted the ideas of 'originality' and 'authority' have become since the Romantic period and despite the main grounds for criticism of Ackroyd's retelling mostly involving the sacrifice of Chaucer's 'original,' the idea of faithfulness to an 'original' seems to be challenged by Chaucer himself:

Chaucer read these authors [Dante, Francis Petrarch, Giovanni Boccacio] along with the ancient Roman poets and drew on them in his own work. Chaucer's Clerk's Tale is based on a Latin version Petrarch made from the last tale in Boccacio's Decameron; in his prologue, the Clerk refers to Petrarch as "lauirat poete" whose sweet rhetoric illuminated all Italy with his poetry. (David and Simpson 2006, 11-12)

Another noteworthy point on the originality of the work in question is hidden in the end of Chaucer's Tales, where Chaucer writes: "Here is ended the book of the tales of Canterbury, compiled by Geoffrey Chaucer, of whose soul Jesus Christ have mercy. Amen" (emphasis mine). ${ }^{22}$ This implies that he 'retold' tales in a period when "originality was not seen as being at odds with imitation in content and form/style" (Tellioğlu 2019, 137). Hence, with 'retelling' taken as 'translation,' even the so-called 'original' here may well be associated with 'translation.'

Additionally, with the translation of his retelling into Turkish, Ackroyd, who explains his way of translating The Canterbury Tales as being in a Chaucerian style (2009, under "A Note on the Text"), seems to undergo a status change and acquisition of authority as Chaucer did through his text production methods in which translation and original authorship went hand in hand. While Ackroyd is designated as the 'translator' in his English work with

22“"Chaucer's Retraction.” Harvard's Geoffrey Chaucer Website, accessed July 1, 2019, https://chaucer.fas.harvard.edu/pages/chaucers-retraction-0. 
Chaucer marked as the 'author,' he gains authorial status in the Turkish translation which presents Ackroyd as the 'author,' calls Seden the 'translator,' and does not even mention 'retelling' in its title. Credit is also given to Chaucer, however, since his name is included in the title: Geoffrey Chaucer'in Canterbury Hikâyeleri (Geoffrey Chaucer's Canterbury tales). Ackroyd's 'authorial status' is also strengthened by the additional note, "translated from the English original" (Ackroyd 2017, 5). Thus, from the perspective of the Turkish literary and cultural system, Ackroyd's retelling can be considered a 'translation-based original. ${ }^{23}$ All things considered, one may argue that translation endowed both Chaucer and Ackroyd with authorial status: through the adoption of translation as a text production method in the former, and through the interlingual translation and presentation of an intralingual translation in the latter.

\section{Conclusion}

Having conducted a theoretical overview of a chain of translational acts reaching from Middle English to Turkish, this study first affirms labeling Ackroyd's retelling of The Canterbury Tales as an 'intralingual translation' based on Ackroyd's designation of his work as 'translation,' Jakobson's definition of 'intralingual translation' ([1959] 2004, 114), and the retelling's satisfaction of the three postulates of '(assumed) translation' put forward by Toury $(1995,33-35)$.

Secondly, the study identifies Seden's Turkish translation of the retelling in question as an 'indirect translation,' i.e., "translation of a translation" (Gambier 2003, 57). A further elaboration on the broader use of the category 'indirect translation' allows for including an interlingual translation of an intralingual translation within the category. After establishing this, the study challenges certain claims and assumptions associated with indirect translations and argues that indirect translation should not be taken as a mere facilitator of interlingual translation, which requires three languages and is turned to only under such conditions. Rather, the study suggests, indirect translation may be profitably employed for any function (e.g., a new interpretation of a work) deemed appropriate in the target text. Consequently, this study advocates elevating indirect translation into a versatile translation category offering further subcategorizations as defined by target systems.

\footnotetext{
${ }^{23}$ For a discussion of translation practices associated with this term within the Ottoman context, see Paker 2014.
} 
Thirdly, the current study introduces a new concept based on Seden's 'indirect translation' and proposes the designation 'retranslation through indirect translation,' where 'indirect' refers to the translation process and 'retranslation' to the existence of pre-existing Turkish translations of The Canterbury Tales. The proposed designation also introduces the possible category of 'retranslation through direct translation' to refer to retranslations of a work that are direct translations from it. This new perspective on retranslation in light of Ackroyd's intralingual retranslation and Seden's interlingual retranslation suggests two additional categorizations for the "type[s] of intervening texts for retranslation" (Alvstad and Rosa 2015, 17-18; Karadă 2019, 46-47): 'single intralingual retranslation' and 'compilative inter- and intralingual retranslation through indirect retranslation.' These proposed terms may contribute to mapping and classifying the components of retranslations and the dynamics of retranslational processes.

Along with requiring intense scrutiny and the proposal of new terms within the frameworks of 'indirect translation' and 'retranslation,' the complex nature of The Canterbury Tales: A Retelling may also illustrate the restrictiveness of making binary categorizations. Evaluating translations based only on dichotomous designations such as 'original' vs. 'translation'-where superiority is assigned to the former and the latter is appreciated only in reference to the text of the so-called 'original'-without consideration of the function of the translated text for the target audience may be unhelpful. It seems as though Chaucer himself may well have dismissed the faithfulness-oriented criticisms The Canterbury Tales: A Retelling received. After all, Ackroyd's purpose in the retelling was to revive audience engagement, and his stated approach to translation mirrored Chaucer's own approach to text production in the source text (i.e. The Canterbury Tales): a retelling of tales through compilation. Senem Öner's (2008) comments regarding 'pseudo' and 'original' are relevant here: "We must acknowledge that every 'original' is always also a 'pseudo-original' and that any claims to 'pure' originality are inherently suspect" (244).

Geoffrey Chaucer'in Canterbury Hikâyeleri, the Turkish translation of Ackroyd's retelling, on the other hand, illustrates how translation can endow authorial status in the sense that Ackroyd, the intralingual translator of Chaucer's The Canterbury Tales, has been attributed authorial status and identity by the Turkish translation's conferral of the title 'author' to him and reference to his work as an 'original.' Hence, the interlingual translational adventure of The Canterbury Tales: A Retelling has recast the authorial character of its 
transLogos 2019 Vol 2 Issue 2

Öztürk Baydere, Hilal, pp. 102-133

trans Dogos

What Could the Translation of a 'Retelling'

Imply for Translation Studies?

(C) Diye Global Communications diye.com.tr|diye@diye.com.tr

translator, positioning the work itself as a 'translation-based original' from the point of view of the Turkish literary and cultural system. This also implies that a translator's authorial status may be reinforced by the way his work travels through other target systems, rather than being merely determined by its source.

Considering all the new terms and perspectives that 'retelling as a translation' has introduced into this study, it is important to remember Maria Tymoczko's (2014) call for Translation Studies "to adopt a broader-in fact, an open-definition of the subject matter at the heart of the discipline, namely translation" (8). Such a broad perspective on translation may help open up new fields of thought within Translation Studies through further empirical research based on "real-life translation phenomena" (Bengi-Öner [1993] 1999, 19). 
transLogos 2019 Vol 2 Issue 2

Öztürk Baydere, Hilal, pp. 102-133

trans Logos

What Could the Translation of a 'Retelling'

A Translation Studies Journal

Imply for Translation Studies?

(C) Diye Global Communications diye.com.tr|diye@diye.com.tr

\section{Appendices}

Figure 1. Cover of The Canterbury Tales: A Retelling

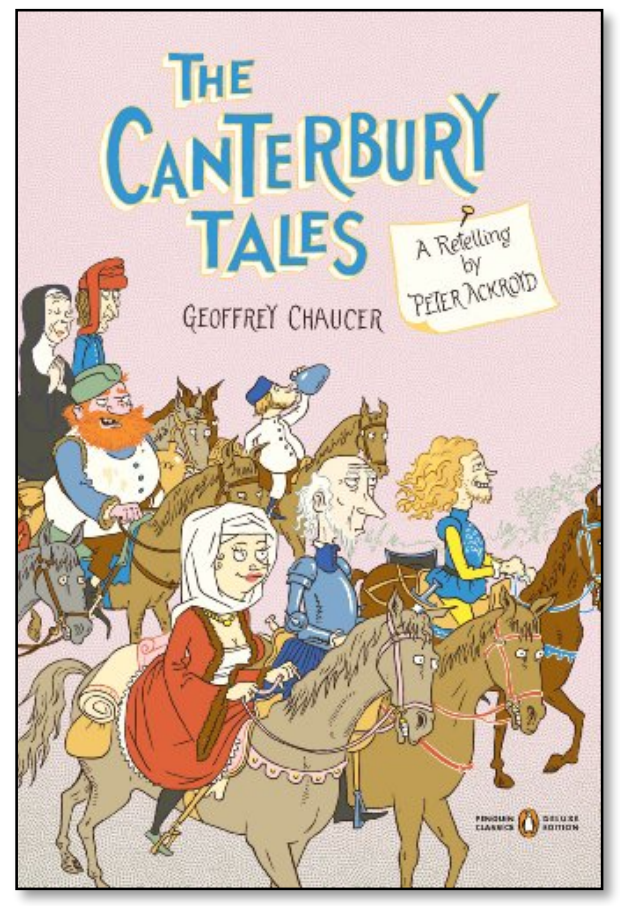

Figure 2. Author and translator information page

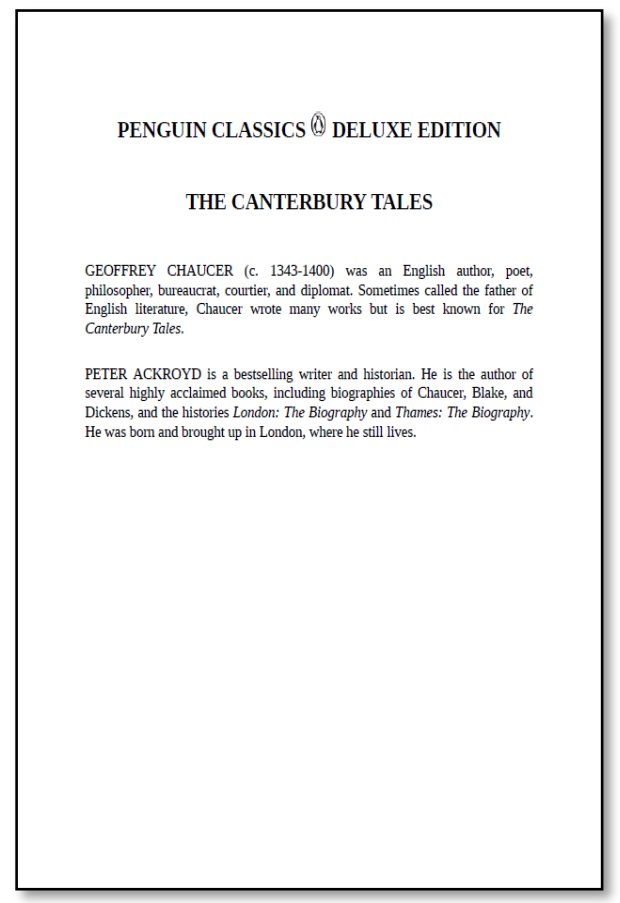


transLogos 2019 Vol 2 Issue 2

Öztürk Baydere, Hilal, pp. 102-133

trans Dogos

What Could the Translation of a 'Retelling'

Imply for Translation Studies?

(C) Diye Global Communications diye.com.tr|diye@diye.com.tr

Figure 3. Cover of Geoffrey Chaucer'ın Canterbury Hikâyeleri

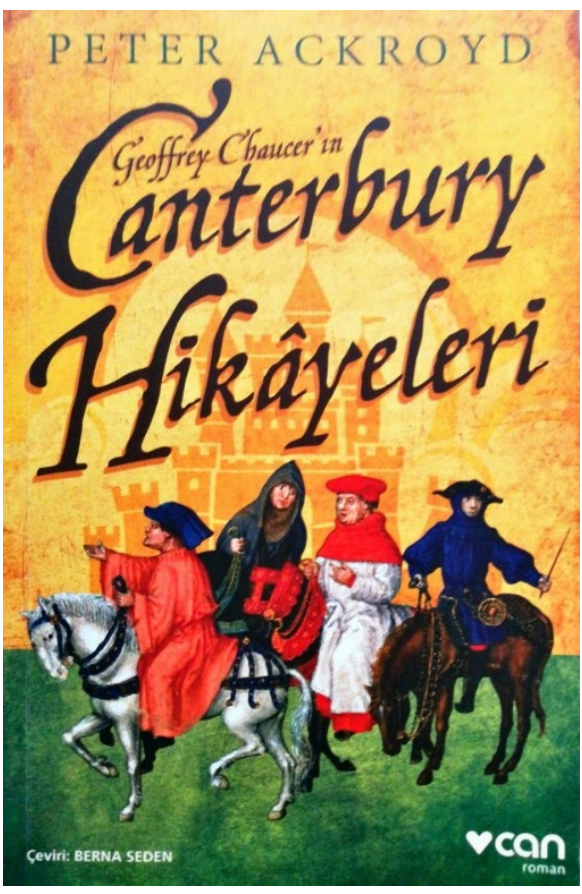

Figure 4. Author and translator information page

PETER ACKROYD, Ingiliz biyografi yazar, romanc1, elestirmen. 1949' da Londra'da doğan Ackroyd eğitimini Cambridge Üniversites' 'nde tamamladı. Daha sonra özel bir bursla iki yıl Yale Üniversitesi'ne gitti. Ackroyd, başta Londra olmak üzere İngiliz tarihi ve kültürüüüzerine romanları ve edebiyat dısıı eserleriyle taninır. Somerset Maugham, Guardian ve Booker ödülleri gibi birçok ödül kazanan yazarın romanları arasinda The Great Fire of London (Büyük Londra YangInI). Oscar Wilde'in Son Vosiveti, Doktor Dee'nin Evi, edebiyat disı kitaplarinin arasinda ise Dickens, London: The Biography (Londra: Biyografi). Shakespeore A Biography (Shakespeare: Bir Biyografi) ve Poe: Kisocik Bir Hayat sayl-

BERNA SEDEN, Dokuz Eylül Üniversitesi Amerikan Kültürü ve Edebiyatı Bölümünden mezun oldu. Sonrasinda gitcięi Ukrayna'da Odessa 1.1. Mechnikor National University'de Tarih eğitimi gördü. Cesesitli gazete ve dergilerde öyküleri, çevirileri yayımland. Ukrayna'da yasamaya devam eden Berna Seden evli ve iki çocuk annesidir. 
transLogos 2019 Vol 2 Issue 2

Öztürk Baydere, Hilal, pp. 102-133

What Could the Translation of a 'Retelling'

Imply for Translation Studies?

(c) Diye Global Communications diye.com.tr|diye@diye.com.tr

\section{References}

Ackroyd, Peter. 1983. The Last Testament of Oscar Wilde. London: Hamish Hamilton. 1985. Hawksmoor. London: Hamish Hamilton.

- 2003. The Clerkenwell Tales. London: Chatto \& Windus.

. 2004. Chaucer: Brief Lives. London: Chatto \& Windus.

—

—. 2010. The Death of King Arthur. London: Penguin Books.

—. 2017. Geoffrey Chaucer'ın Canterbury Hikâyeleri. Translated by Berna Seden. Istanbul: Can.

Alvstad, Cecilia, and Alexandra Assis Rosa. 2015. "Voice in Retranslation: An Overview and Some Trends." Target 27 (1): 3-24. doi:10.1075/target.27.1.00int.

Barrington, Candace, and Jonathan Hsy. 2015. "Global Chaucers." In Medieval Afterlives in Contemporary Culture, edited by Gail Ashton, 147-156. London: Bloomsbury.

Bassnett, Susan. 2001. "Shakespeare's in Danger: We Have to Act Now to Avoid a Great Tragedy." Independent. November 14. Accessed July 1, 2019. https://www.independent.co.uk/news/education/education-news/shakespeares-indanger-we-have-to-act-now-to-avoid-a-great-tragedy-9159195.html.

- 2006. "Writing and Translating." In The Translator as Writer, edited by Susan Bassnett and Peter Bush, 173-182. London: Continuum.

- 2011. "Prologue." In Tradition, Translation, Trauma: The Classic and the Modern, edited by Jan Parker and Timothy Mathews. Oxford: Oxford University Press.

Baydere, Muhammed. 2019. "Çalıkuşu'nun Çeviri Serüveni." [The translational adventure of Çalıkuşu.] Unpublished manuscript, last modified July 3. Microsoft Word file.

Baydere, Muhammed, and Ayşe Banu Karadağ. 2019. “Çalıkuşu'nun Öz-Çeviri Serüveni Üzerine Betimleyici Bir Çalışma." [A descriptive study on the self-translation adventure of Çalıkuşu.] In "2nd International Rumeli Symposium [Language, Literature, Translation]," edited by Yakup Yılmaz and Fatih Başpınar. Special Issue, RumeliDE Journal of Language and Literature Studies, no. 5, 314-333. doi:10.29000/rumelide.606165.

Beckett, Sandra L. 2003. "When Modern Little Red Riding Hoods Cross Borders... or Don't..." Meta 48 (1-2): 15-30. doi:10.7202/006955ar. 
Bengi-Öner, Işıı. (1993) 1999. “Çeviri Eleştirisi Bağlamında Eleştirel Bilincin Oluşması ve Eleştiri, Üst-Eleştiri, Çeviribilim İlişkileri.” [Forming critical consciousness within the context of translation criticism and the relations between criticism, metacriticism, and Translation Studies.] Chap. 3 in Çeviri Bir Süreçtir... Ya Çeviribilim? [Translation is a process... What about Translation Studies?] Istanbul: Sel.

Berk Albachten, Özlem. 2013. "Intralingual Translation as 'Modernization' of the Language: The Turkish Case." Perspectives $21 \quad$ (2): 257-271. doi:10.1080/0907676X.2012.702395.

2014. "Intralingual Translation: Discussions within Translation Studies and the Case of Turkey." In A Companion to Translation Studies, edited by Sandra Bermann and Catherine Porter, 573-585. West Sussex: Wiley Blackwell.

2015. "The Turkish Language Reform and Intralingual Translation." In Tradition, Tension and Translation in Turkey, edited by Şehnaz Tahir Gürçağlar, Saliha Paker, and John Milton, 165-180. Amsterdam: John Benjamins.

. 2019. "Challenging the Boundaries of Translation and Filling the Gaps in Translation History: Two Cases of Intralingual Translation from the 19th-Century Ottoman Literary Scene." In Moving Boundaries in Translation Studies, edited by Helle V. Dam, Matilde Nisbeth Brøgger, and Karen Korning Zethsen. London: Routledge. PDF e-book.

Berk Albachten, Özlem, and Şehnaz Tahir Gürçağlar. 2019. "The Making and Reading of a Bibliography of Retranslations." In Perspectives on Retranslation: Ideology, Paratexts, Methods, edited by Özlem Berk Albachten and Şehnaz Tahir Gürçağlar, 212-230. New York: Routledge.

Birkan Baydan, Esra. 2015. "Ideological Encounters: Islamic Retranslations of the Western Classics." In Tradition, Tension and Translation in Turkey, edited by Şehnaz Tahir Gürçağlar, Saliha Paker, and John Milton, 233-251. Amsterdam: John Benjamins.

Boy, Hülya. 2019a. "The Picture of Dorian Gray'in Diliçi ve Dillerarası Çevirileri Üzerine Kavramsal Sorgulamalar." [Conceptual reflections on the intra-/inter-lingual translations of The Picture of Dorian Gray.] Unpublished manuscript, last modified July 3. Microsoft Word file.

2019b. "Yeniden Yazım ve Yeniden Çeviri Bağlamında Dorian Gray'in Portresi." [The Picture of Dorian Gray within the context of rewriting and retranslation.] In Çeviri Üzerine Gözlemler [Observations on translation], edited by Seda Taş, 151-172. Istanbul: Hiperyayın.

Canl1, Gülsüm. 2018. "Relocating Self-Translation from the Interlingual to Intralingual: Faulkner as a Self-Translauthor." transLogos Translation Studies Journal 1 (1): 41 63. doi:10.29228/transLogos.1/1.8. 
. 2019a. "Bir Çeviri Eylemi Olarak Yeniden Anlatım: 'The Hogarth Shakespeare' Projesi." [Retelling as a translational practice: 'The Hogarth Shakespeare' project.] In "2nd International Rumeli Symposium [Language, Literature, Translation]," edited by Yakup Yılmaz and Fatih Başpınar. Special Issue, RumeliDE Journal of Language and Literature Studies, no. 5, 377-386. doi:10.29000/rumelide.606220.

2019b. "William Faulkner'1n Sanctuary Adlı Romanının Kaynak ve Erek Dizgedeki Çeviri Serüveni: Diliçi Çeviri, Öz-Çeviri, Yeniden Çeviri ve Dolaylı Çeviri Kavramları Işı̆ı̆ında Bir İnceleme." [The translational adventure of William Faulkner's Sanctuary in source and target systems: An analysis in the light of intralingual translation, self-translation, retranslation and indirect translation.] $\mathrm{PhD}$ diss., Y1ldız Technical University.

Canseven, Cansu. 2017. "Konuşmalar: Diliçi Çeviri." [Conversations: Intralingual translation.] T24. April 13. https://t24.com.tr/k24/yazi/konusmalar-dilici-ceviri1,1152.

Chaucer, Geoffrey. 1993. Canterbury Hikâyeleri: Genel Prolog [The Canterbury tales: General prologue]. Translated by Burçin Erol. Istanbul: Gündoğan.

(1994) 2010. Canterbury Hikâyeleri [The Canterbury tales]. Translated by Nazmi Ağıl. Istanbul: Yapı Kredi.

2017. Canterbury Hikâyeleri [The Canterbury tales]. Translated by Sibel Alaş. Istanbul: Büyülü Fener.

Crystal, David. 2002. "To Modernize or Not to Modernize: There is No Question." Around the Globe 21:15-17. http://www.davidcrystal.com/?fileid=-4232.

David, Alfred, and James Simpson. 2006a. "The Canterbury Tales." In The Norton Anthology of English Literature, edited by Stephen Greenblatt and M. H. Abrams, 1:216-218. New York: W. W. Norton.

—. 2006b. "The Middle Ages." In The Norton Anthology of English Literature, edited by Stephen Greenblatt and M. H. Abrams, 1:1-23. New York: W. W. Norton.

Delabastita, Dirk. 2017. “'He Shall Signify from Time to Time.' Romeo and Juliet in Modern English.” Perspectives 25 (2): 189-213. doi:10.1080/0907676X.2016.1234491.

Demirkol Ertürk, Şule. 2019. "Retranslating and Repackaging a Literary Masterpiece from a Peripheral Language: The Functions of Paratexts in Recontextualizing Literary Translations." In Studies from a Retranslation Culture: The Turkish Context, edited by Özlem Berk Albachten and Şehnaz Tahir Gürçağlar, 137-154. Singapore: Springer.

Deveson, Tom, and Susan Bassnett. 2001. "Modernizing Shakespeare." Around the Globe 20:32-33. 
Eker-Roditakis, Arzu. 2019. "Repackaging, Retranslation, and Intersemiotic Translation: A Turkish Novel in Greece." In Perspectives on Retranslation: Ideology, Paratexts, Methods, edited by Özlem Berk Albachten and Şehnaz Tahir Gürçağlar, 67-86. New York: Routledge.

Erkul Yağc1, A. Selin. 2019. "Retranslation, Paratext, and Recontextualization: Le Comte de Monte Cristo and The Hound of Baskervilles in Turkish (Re)translations." In Studies from a Retranslation Culture: The Turkish Context, edited by Özlem Berk Albachten and Şehnaz Tahir Gürçağlar, 155-175. Singapore: Springer.

Eubanks, Adelheid. 2012. "Writing from the Margins, Writing in the Margins." In Exile through a Gendered Lens: Women's Displacement in Recent European History, Literature, and Cinema, edited by Gesa Zinn and Maureen Tobin Stanley, 83-97. New York: Palgrave Macmillan.

Even-Zohar, Itamar. (1978) 2004. "The Position of Translated Literature within the Literary Polysystem.” In The Translation Studies Reader, edited by Lawrence Venuti, 192 197. London: Routledge. PDF e-book.

Gambier, Yves. 2003. "Working with Relay: An Old Story and a New Challenge." In Speaking in Tongues: Language Across Contexts and Users, edited by Luis Pérez González, 47-66. Valencia: University of Valencia Press.

Geçmen, Kerem. 2018. "Retranslation and Shifting Constraints." transLogos Translation Studies Journal 1 (1): 25-40. doi:10.29228/transLogos.1/1.7.

Greer, Germaine. 2009. "The Canterbury Tales." Financial Times. April 20. https://www.ft.com/content/a7548b72-2add-11de-8415-00144feabdc0.

Gutt, Ernst August. 1989. “Translation and Relevance.” PhD diss., University of London.

Güneş, Alper Zafer. 2018. "The Retranslation of The Time Regulation Institute: A Project of Respect or Prejudice?” In Çeviribilimde Güncel Tartışmalardan Kavramsal Sorgulamalara [From recent discussions to conceptual reflections in Translation Studies], edited by Seda Taş, 379-411. Istanbul: Hiperyayın.

- 2019. "A Conceptual Inquiry: What May Retranslation Offer for Translation Studies Research?” transLogos Translation Studies Journal 2 (1): 47-67. doi:10.29228/transLogos.2/1.3.

Jakobson, Roman. (1959) 2004. "On Linguistic Aspects of Translation.” In The Translation Studies Reader, edited by Lawrence Venuti, 113-118. London: Routledge. PDF ebook.

Jianzhong, Xu. 2003. "Retranslation: Necessary or Unnecessary." Babel 49 (3): 193-202. doi:10.1075/babel.49.3.02jia. 
transLogos 2019 Vol 2 Issue 2

Öztürk Baydere, Hilal, pp. 102-133

trans Dogos

A Translation Studies Journal

What Could the Translation of a 'Retelling'

Imply for Translation Studies?

(C) Diye Global Communications diye.com.tr|diye@diye.com.tr

Kafaoğlu Büke, Asuman. 2017. "Canterbury Hikâyeleri.” [The Canterbury tales.] Cumhuriyet Kitap. June 1. https://www.cumhuriyetarsivi.com/katalog/4200/yazar/25521ASUMAN+KAFACIO\%20LI+B\%C3\%9CKE/2017/6/1.xhtml.

Kalem Bakkal, Asl1. 2019. "From the 'Real' Author to the 'Real' Reader: Manipulation in Translation." transLogos Translation Studies Journal 2 (1): 85-101. doi:10.29228/transLogos.2/1.5.

Karadağ, Ayşe Banu. 2008. Çevirinin Tanıklı̆̆ında 'Medeniyet'in Dönüşümü [Transformation of 'civilization' in the witness of translation]. Istanbul: Diye.

. 2017. "Çeviri, Tarih ve Bellek: Diliçi Edebi Çeviriler Bağlamında Bir İnceleme." [Translation, history, and memory: An analysis within the context of intralingual literary translations.] Paper presented at the 5th International Western Cultural and Literary Studies Symposium, Sivas, October 4-6.

2019. "Çeviri Yoluyla Geçmiş, Şimdi ve Gelecek Arasında Köprüler Kurmak." [Building bridges between the past, present and future through translation.] In Çeviribilimde Araştırmalar [Research in Translation Studies], edited by Seda Taş, 3158. Istanbul: Hiperyayın.

Karas, Hilla. 2020. "Intelligibility and the Reception of Translations." Perspectives 28 (1): 24-42. doi:10.1080/0907676X.2019.1612929.

Kim, Kyung Hye. 2017. "Retranslation as a Socially Engaged Activity: The Case of The Rape of Nanking." Perspectives 26 (3): 391-404. doi:10.1080/0907676X.2017.1388413.

Konca, İrem. 2019. "The Turkish Retranslations of Marx's Das Kapital as a Site of Intellectual and Ideological Struggle." In Studies from a Retranslation Culture: The Turkish Context, edited by Özlem Berk Albachten and Şehnaz Tahir Gürçağlar, 8194. Singapore: Springer.

Koskinen, Kaisa. 2019. "Revising and Retranslating." In The Routledge Handbook of Literary Translation, edited by Kelly Washbourne and Ben Van Wyke. London: Routledge. Google Book.

Koskinen, Kaisa, and Outi Paloposki. 2010. "Retranslation." In Handbook of Translation Studies, edited by Yves Gambier and Luc van Doorslaer, 1:294-298. Amsterdam: John Benjamins.

Krishnamurthy, Ramesh. 2011. "Indian Tradition.” In Routledge Encyclopedia of Translation Studies, edited by Mona Baker and Gabriela Saldanha, 449-458. London: Routledge.

Kunz, Keneva. 2011. "Icelandic Tradition." In Routledge Encyclopedia of Translation Studies, edited by Mona Baker and Gabriela Saldanha, 442-449. London: Routledge. 
Leatherbarrow, William J. 2002. Review of Retelling Dostoyevsky: Literary Responses and Other Observations, by Gary Adelman. The Modern Language Review 97 (3): 780781. doi:10.2307/3737585.

Marin-Lacarta, Maialen. 2017. 2017. "Indirectness in Literary Translation: Methodological Possibilities." In "Indirect Translation: Theoretical, Methodological and Terminological Issues," edited by Alexandra Assis Rosa, Hanna Pięta, and Rita Bueno Maia. Special Issue, Translation Studies 10 (2): 133-149. doi:10.1080/14781700.2017.1286255.

McGregor Kendal, Gordon. 2008. "Translation as Creative Retelling: Constituents, Patterning and Shift in Gavin Douglas' Eneados." PhD diss., University of St. Andrews.

Mehtonen, P. M., and Jussi-Pekka Hakkarainen. 2013. "Retelling The Kalevala: From Martin Buber's Mysticism to Third Reich Cultural Politics." Deutsche Vierteljahrsschrift für Literaturwissenschaft und Geistesgeschichte $87 \quad$ (1): 123-139. doi:10.1007/BF03375854.

Mørup Hansen, Susanne. 2005. "Hans Christian Andersen - Told for Children." Perspectives 13 (3): 163-177. doi:10.1080/09076760508668989.

Mossop, Brian. 2016. “'Intralingual Translation': A Desirable Concept?” Across Languages and Cultures 17 (1): 1-24. doi:10.1556/084.2016.17.1.1.

Oittinen, Riitta. 2008. "From Thumbelina to Winnie-the-Pooh: Pictures, Words, and Sounds in Translation." Meta 53 (1): 76-89. doi:10.7202/017975ar.

Onega, Susan. 1996. "Interview with Peter Ackroyd." Twentieth Century Literature 42 (2): 208-220. doi:10.2307/441734.

Öner, Senem. 2008. "Folk Songs, Translation and the Question of (Pseudo-)Originals." The Translator 14 (2): 229-246. doi:10.1080/13556509.2008.10799257.

- 2013. "Translator: Expert of 'What'? Translator Training and the Changing/Changeful Identity of the Translator." In "English Studies." Special Issue, Journal of History Culture and Art Research 2 (2): 69-78. doi:10.7596/taksad.v2i2.232.

Öner Bulut, Senem. 2018. "Sadakat-Merkezli Çeviri Söylemini Lacancı Psikanaliz Çerçevesinde Yeniden Düşünmek." [Re-thinking faithfulness-centered translation discourse through Lacanian psychoanalysis.] In "1st International Rumeli Symposium [Language, Literature, Translation]," edited by Yakup Y1lmaz and Fatih Başpınar. Special Issue, RumeliDE Journal of Language and Literature Studies, no. 4, 266-273. doi:10.29000/rumelide.454277. 
transLogos 2019 Vol 2 Issue 2

Öztürk Baydere, Hilal, pp. 102-133

trans Dogos

A Translation Studies Journal

What Could the Translation of a 'Retelling'

Imply for Translation Studies?

(C) Diye Global Communications diye.com.tr|diye@diye.com.tr

Özmen, Ceyda. 2019. "Retranslating in a Censorial Context: H. C. Armstrong's Grey Wolf in Turkish.” In Perspectives on Retranslation: Ideology, Paratexts, Methods, edited by Özlem Berk Albachten and Şehnaz Tahir Gürçağlar, 45-64. New York: Routledge.

Öztürk Baydere, Hilal. 2018. "The Canterbury Tales'in İngilizce ve Türkçedeki Çeviri Macerasını Yeniden Düşünmek." [Revisiting the translational adventure of The Canterbury Tales in English and Turkish.] Paper presented at Enriching Translation Studies through Rereadings Symposium, Istanbul, March 28.

2019. "Türk Edebiyatını Diliçi Çevirilerden Okumak: Osmanlıcada ve Günümüz Türkçesinde Refik Halid'in Guguklu Saat'i." [Reading Turkish literature through intralingual translations: Refik Halid's Guguklu Saat in Ottoman and modern Turkish.] In Çeviri Üzerine Gözlemler [Observations on translation], edited by Seda Taş, 223-241. Istanbul: Hiperyayın.

Pagello, Federico. 2013. “A. J. Raffles and Arsène Lupin in Literature, Theatre, and Film: On the Transnational Adaptations of Popular Fiction (1905-30)." Adaptation 6 (3): 268282. doi:10.1093/adaptation/apt002.

Paker, Saliha. 2014. "Terceme, Te'lîf ve Özgünlük Meselesi." [The issue of terceme, te'lif and originality.] In Metnin Hâlleri: Osmanlı'da Telif, Tercüme ve Şerh [The states of text: Original, translation and commentary in the Ottoman tradition], edited by Hatice Aynur, Müjgân Çakır, Hanife Koncu, Selim S. Kuru, and Ali Emre Özyıldırım, 36-71. Istanbul: Klasik.

Perteghella, Manuela. 2013. "Translation as Creative Writing." In A Companion to Creative Writing, edited by Graeme Harper, 195-212. West Sussex: Wiley Blackwell.

Pięta, Hanna. 2014. "What Do (We Think) We Know about Indirectness in Literary Translation? A Tentative Review of the State-of-the-Art and Possible Research Avenues." In Traducció Indirecta En La Literatura Catalana [Indirect translation in Catalan literature], edited by Ivan Garcia Sala, Diana Sanz Roig, and Bozena Zaboklicka, 15-34. Lleida: Punctum.

2017. "Theoretical, Methodological and Terminological Issues in Researching Indirect Translation: A Critical Annotated Bibliography." In "Indirect Translation: Theoretical, Methodological and Terminological Issues," edited by Alexandra Assis Rosa, Hanna Pięta, and Rita Bueno Maia. Special Issue, Translation Studies 10 (2): 198-216. doi:10.1080/14781700.2017.1285248.

Pimentel, Marcia. 1998. "The Give and Take of Retelling: Translating La Mujer Desnuda." Translation Review 56 (1): 49-53. doi:10.1080/07374836.1998.10523731.

Pym, Anthony. 2011. "Translation Research Terms: A Tentative Glossary for Moments of Perplexity and Dispute." In Translation Research Projects, edited by Anthony Pym, 3:75-110. Tarragona: Intercultural Studies Group. 
Ralarala, Monwabisi K. 2014. "Transpreters' Translations of Complainants' Narratives as Evidence: Whose Version Goes to Court?" The Translator 20 (3): 377-395. doi:10.1080/13556509.2014.934002.

Reis, Huriye. 2001. "The Canterbury Tales in Turkish: A Cultural Translation.” Çeviribilim ve Uygulamalarl Dergisi, no. 11, 47-58. http://fs.hacettepe.edu.tr/ceviribilim/dosyalar/sayilar/2001.pdf.

Ringmar, Martin. 2012. "Relay Translation." In Handbook of Translation Studies, edited by Yves Gambier and Luc van Doorslaer, 3:141-144. Amsterdam: John Benjamins.

Rogers, Byron. 2009. "Instead of the Poem." The Spectator. May 13. https://www.spectator.co.uk/2009/05/instead-of-the-poem/.

Rosa, Alexandra Assis, Hanna Pięta, and Rita Bueno Maia. 2017. "Theoretical, Methodological and Terminological Issues Regarding Indirect Translation: An Overview." In "Indirect Translation: Theoretical, Methodological and Terminological Issues," edited by Alexandra Assis Rosa, Hanna Pięta, and Rita Bueno Maia. Special Issue, Translation Studies 10 (2): 113-132. doi:10.1080/14781700.2017.1285247.

Screnock, John. 2018. "Is Rewriting Translation? Chronicles and Jubilees in Light of Intralingual Translation." Vetus Testamentum 68 (3): 475-504. doi:10.1163/15685330-12341296.

Shuttleworth, Mark, and Moira Cowie. (1997) 2014. Dictionary of Translation Studies. London: Routledge.

Špirk, Jaroslav. 2011. "Ideology, Censorship, Indirect Translations and Non-Translation: Czech Literature in 20th-Century Portugal.” PhD diss., Charles University.

Tahir Gürçağlar, Şehnaz. 2011. "Retranslation.” In Routledge Encyclopedia of Translation Studies, edited by Mona Baker and Gabriela Saldanha, 233-236. London: Routledge.

Tellioğlu, Banu. 2019. “Özgünün Kökeni ve Çeviride Telif Hakları Meselesi.” [The origin of the original and the issue of translation copyright.] In Çeviribilimde Araştırmalar [Research in Translation Studies], edited by Seda Taş, 123-148. Istanbul: Hiperyayın.

Toury, Gideon. 1995. Descriptive Translation Studies - and Beyond. Amsterdam: John Benjamins.

Tymoczko, Maria. 2014. Enlarging Translation, Empowering Translators. London: Routledge.

Van Poucke, Piet. 2019. "Retranslation History and Its Contribution to Translation History: The Case of Russian-Dutch Retranslation." In Perspectives on Retranslation: Ideology, Paratexts, Methods, edited by Özlem Berk Albachten and Şehnaz Tahir Gürçağlar, 195-211. New York: Routledge. 
transLogos 2019 Vol 2 Issue 2

Öztürk Baydere, Hilal, pp. 102-133

$\underset{\text { A ransatation Studies ournal }}{\operatorname{trans}}$

What Could the Translation of a 'Retelling'

Imply for Translation Studies?

(c) Diye Global Communications diye.com.tr|diye@diye.com.tr

Wakabayashi, Judy. 2011. "Fictional Representations of Author-Translator Relationships." Translation Studies 4 (1): 87-102. doi:10.1080/14781700.2011.528684.

- 2012. "Secular Translation: Asian Perspectives." In The Oxford Handbook of Translation Studies, edited by Kirsten Malmkjær and Kevin Windle. Oxford: Oxford University Press. PDF e-book.

Washbourne, Kelly. 2013. "Nonlinear Narratives: Paths of Indirect and Relay Translation." Meta 58 (3): 607-625. doi:10.7202/1025054ar.

Widman, Julieta. 2019. "Translation Modalities Method in Retranslation Analysis: A Paixão Segundo G. H. in English." In Perspectives on Retranslation: Ideology, Paratexts, Methods, edited by Özlem Berk Albachten and Şehnaz Tahir Gürçağlar, 148-165. New York: Routledge.

Wong, Laurence. 1998. "Lin Shu's Story-Retelling as Shown in His Chinese Translation of La Dame aux Camélias.” Babel 44 (3): 208-233. doi:10.1075/babel.44.3.03won.

Woodsworth, Judith. 2012. "Translators and the Emergence of National Literatures." In Translators through History, edited by Jean Delisle, 61-92. Amsterdam: John Benjamins.

Zethsen, Karen Korning. 2018. "Access is not the Same as Understanding. Why Intralingual Translation is Crucial in a World of Information Overload." Across Languages and Cultures 19 (1): 79-98. doi:10.1556/084.2018.19.1.4.

Zethsen, Karen Korning, and Aage Hill-Madsen. 2016. "Intralingual Translation and Its Place within Translation Studies: A Theoretical Discussion.” Meta 61 (3): 692-708. doi:10.7202/1039225ar.

Ziemann, Zofia. 2019. "Extratextual Factors Shaping Preconceptions About Retranslation: Bruno Schulz in English." In Perspectives on Retranslation: Ideology, Paratexts, Methods, edited by Özlem Berk Albachten and Şehnaz Tahir Gürçağlar, 87-103. New York: Routledge. 